\title{
Technical and Economic Evaluation of China's Integrated Gasification Combined Cycle: The Case of Yantai Project
}

\author{
Dapeng Liang ${ }^{1 *}$, Xinpeng Xing ${ }^{1}$, Weidong Shen ${ }^{2}$ \\ ${ }^{1}$ School of Management, Harbin Institute of Technology, Harbin, China; ${ }^{2}$ Shandong Electric Power Engineering Consulting Institu- \\ tion Corp. Ltd, Jinan, China. \\ Email: *1dp740920@hotmail.com
}

Received March $5^{\text {th }}, 2013$; revised April $5^{\text {th }}, 2013$; accepted April 15 ${ }^{\text {th }}, 2013$

Copyright (C) 2013 Dapeng Liang et al. This is an open access article distributed under the Creative Commons Attribution License, which permits unrestricted use, distribution, and reproduction in any medium, provided the original work is properly cited.

\begin{abstract}
Due to the advantages such as high efficiency of electricity generation and high degree of cleanness, Integrated Gasification Combined Cycle (IGCC) power plant represents the direction of development for all fired power plants in China. This essay analyzes the technical requirements and economic attributes of the Chinese IGCC power plant of $400 \mathrm{MW}$ level in plan. It is both necessary and possible for China to develop IGCC power plant with the technical foundation available. The biggest obstacle facing the development of IGCC is the huge amount of investment and high cost of electric generation. According to the sensitivity analysis, investment is the main element affecting the cost of power generation. Though it is difficult to control investment in the present phase, with restricting elements like technique and facility, smooth operation of the project could still be ensured through government's preferential policies toward IGCC power plant, such as setting price for clean electricity, offering investment subsidies and preferential taxes. The premise for such policies is a determined and consistent development strategy of IGCC technique.
\end{abstract}

Keywords: IGCC; Technical Economic Evaluation; Coal Fired Power Plant

\section{Introduction}

IGCC, shorthand for Integrated Gasification Combined Cycle, is one of the most outstanding new clean coal electricity generation techniques with high efficiency. In recent decades, drawing more and more attention from many countries all over the world, it has successfully entered into the phase of commercial operation [1].

The combustion gas turbine could only be fueled by combustible gas and liquidated fuel, which limits its scope of application. The research and development of gasification and filtering techniques provide access to new sources for combustion gas turbines. With coal as the fuel, synthetic gas is created through gasifier, and is applied to combustion gas turbine after the filtering process such as dedusting and desulfuration. The combustion gas turbine drives steam cycle, and then forms The Integrated Gasification Combined Cycle [2,3].

The outstanding advantages of IGCC are as follows:

- High thermal efficiency. The existing commercial IGCC power plant in the international market boosts a net efficiency of $43 \%, 5 \%$ higher than the traditional

"Corresponding author. coal fired units.

- Low pollution. It enjoys a desulfuration rate of $99 \%$ with sulfur recovery function, and low $\mathrm{NO}_{\mathrm{x}}$ emission rate which equals to $1 / 20$ of the traditional coal fired units. Moreover, the dust emission is close to zero.

- Low water consumption, accounting for $1 / 2-2 / 3$ of the consumption of traditional coal fired units.

- Multifunctional. With the poly-generation technology, it could supply electricity, heat, gasified coal and chemical material at the same time.

In 2007, the electric power generating capacity across China was about 713 million $\mathrm{kW}$, with the annual electric production at 3.28 trillion $\mathrm{kWh}$, of which thermal power generating capacity accounted for 554 million $\mathrm{kW}$, with annual electric production standing at 2.720 trillion $\mathrm{kWh}$. $83 \%$ of the electricity came from a thermal power plant with coal as the main source of energy. Against the backdrop of fully developing "Low Carbon Fuel Economy", it is estimated that by the year 2030, the electric power generating capacity across China will reach 2 billion 14 million $\mathrm{kW}$ with the annual electric production at 8.62 trillion $\mathrm{kWh}$, of which thermal power generating capacity accounts for 1.179 billion $\mathrm{kW}$, with annual electric pro- 
duction standing at 5.88 trillion $\mathrm{kWh}$. Electricity comes from the thermal power plant takes up $68.2 \%$. IGCC sets the trend for the development of the thermal power plant. According to the goal set in China's energy program, by 2015 , IGCC will take up $6 \%$ of the thermal power generating capacity growth, reaching 3 million 310 thousand $\mathrm{kW}$. By 2030 , IGCC will take up $19 \%$ of the thermal power generating capacity growth, reaching 27.1 million $\mathrm{kW}$ [4]. In the coming decades, China's electricity supply will still rely on coal fired power plant. It is interest of China's energy sustainable development to independently exploit clean coal fired electricity generation technique with low cost, and high efficiency, as well as other comprehensive utilization techniques.

In February 2006, the State Council launched The Outline of the National Program for Long- and Mediumterm Scientific and Technological Development 20062020, and set IGCC, poly-generation technology based on coal gasification, and multiple utilization and control technique and equipment of pollutant emission during coal combustion as the prior theme. In June 2007, the State Council launched China national climate change program, clearly stating that the government will further strengthen the development and transmission of advanced appropriate technology, with IGCC technique, poly-generation technology based on coal gasification, and $\mathrm{CO}_{2}$ gathering, utilization and storage techniques etc, as the main focus. With the development of key techniques of IGCC and the successful operation of the demonstration equipment in other countries, the condition for China to develop IGCC is ripe. With Huaneng green coal fired electricity project as an example, IGCC project is getting momentum in China. China has about 20 IGCC projects in plan, including Shenhua IGCC polygeneration technology project in Wenzhou, with the total investment standing at 8.8 billion; China Power Investment Corporation's IGCC project in Langfang, Hebei, which has got the environmental assessment reply from the ministry of environment in April 2008; Huadian IGCC project with capacity of $200 \mathrm{MW}$ in Banshan, Zhejiang, whose preliminary feasibility study report has passed inspection; in Dongguan, Guangdong electrochemical Integrated Gasification Combined Cycle with capacity of $4 \times 200 \mathrm{MW}$, using IGCC technique independently developed by Institute of Engineering Thermophysics Chinese Academy of Science; the first phase of Sino-US Mongolia power plant construction with methyl alcohol production capacity of $2 \times 80 \quad 10,000$ ton/year and integrated gasification combined cycle with capacity of $800 \mathrm{MW}$ etc. [5]. China still stays in the primary level with investment stopped in some project after the demonstration work at the earlier stage, due to China's limited experience with the construction of IGCC power plant, the complexity of the technique, and the huge in- vestment. IGCC project at Yantai power plant is an example. This essay tries to unveil the major obstacles and inspiration methods during the process of investment in IGCC technique in China through the technical economic analysis of the project of IGCC demonstration work at Shandong power plant.

\section{The Background of the IGCC Project in Yantai}

As the first demonstration IGCC project in China, Yantai IGCC project was finished the preliminary feasibility study in January 1997, and within the same year, it passed Shandong Electric Power Corporation's inspection and submitted project proposal in March. In September 1999, the state planning commission approved and initiated the project. Between the year of 1997 to 2002 , according to the requirement of the state planning commission and the State Grid, cooperative program inquiry was drawn up. On 28th January 2002, IGCC demonstration project cooperation program inquiry in Yantai, Shandong was publicly released. During November and December in 2002, clarification and negotiation with the bidder was underway. In June 2003, the first draft of bidding evaluation about the technical and commercial parts was finished. This project has originnally planned to be started in June, 2004, and put into production in June, 2007. However, up to now, this project has not started.

Three main reasons have caused the delay of Yantai IGCC project. First, China has a dispute on the necessity of IGCC project construction. Chinese government has not formulated and promoted core leadership institution of energy strategy for a long time, which causes the current system lack of an effective interest driving mechanism. Second, the key technologies and equipments rely too much on the foreign enterprise, which causes high investment and cost. In the negotiation, China was in a passive position. Hence, the foreign quoted price was very high. The static investment was 0.44 billion dollars, among which the foreign equipment and technology investment in air separation, gasification, generator and public part has reached more than $50 \%$. Third, the ownership of this project is a bit controversial, which causes the responsibility unclear. Yantai IGCC project was initially constructed by The State Power Corporation, Shandong Electric Power Group Corporation, Yantai Electic Power Development Co., Ltd, and Shandong International Trust and Investment Corporation. As the state power system reformed, The State Grid Corporation was in charge of Yantai IGCC project to accelerate technology innovation and science progress, but it was not responsible for power generation business, so it is not attractive for it to bear great risks to construct IGCC demonstration project. 
This project is funded by four shareholders: State Grid, Shandong Electric Power Corporation,

According to the arrangement of the state planning commission and the investors, the implementation of the project falls into four phases:

- In the first phase, release the cooperative program inquiry to the public, nominate the licenser (initiator) for coal gasification electricity generation technology, and the suppliers for the main equipment of gasification island and the power island. Finally sign the draft contract after a series of inquiry, assessment and negotiation.

- In the second phase, the initiator puts forward the detailed process design plan of the factory, the owners choose the experienced international engineering corporation or consultant firm through the bidding process to form the design union with Chinese institute of design. The work is carried out according to the principle of Sino-foreign cooperation, with the foreign party shouldering the technical responsibility and the Chinese party actively participating in the design process. At that time, this project was the first IGCC demonstration project in China, and in order to achieve success in the perspectives such as the overall performance, quality, rate of progress and cost control, the management style of the project management team, comprising members from the both sides is adopted after discussion.

- In the third phase, the general design union is in charge of composing the bidding documents of the respective units, and it is the owners' responsibility to invite bids.

- In the fourth phase, the general design union is in charge of construction drawing design and the owners are responsible for select construction contractor unit by inviting bids.

In conclusion, the main participators of the project are as follows: gasification licensers submitting the bids include American Texaco and Netherland Shell corporations; gasification equipment suppliers including Spanish Bahia de Bizkaia Electricidad and German Alstom corporations; power island suppliers including American General Electric and German Siemens corporations.

\section{The Technical Requirement of Yantai IGCC Project}

The planning of IGCC project at Yantai power plant is carried out according to the standard of $2 \times 400 \mathrm{MW}$ level or $2 \times 300 \mathrm{MW}$ level. One set will be completed as the first IGCC demonstration project, which is divided into gasification island, power island, desulfuration island, instrument controls island, space division island, and BOP island, according to the functions of IGCC. Four potential installment plans were provided at that time.
- Texaco + GE plan.

- Texaco + Siemens plan.

- Shell + GE plan.

- Shell + Siemens plan.

Three main aspects of the technical plan of Yantai IGCC project were discussed: the gasification technique, desulfuration technique, integrated gasification combined cycle technique and space division technique. Some basic requirements were set during the discussion process:

- The gasification process needs to be carried out with entrained flow oxygen gasification technique, and dry feedstock or wet feedstock is adopted. High pressure and medium pressure steam should be recovered as the by-product of synthetic gas with sensible heat.

- Dry and wet dedusting technique should be adopted to meet the dust content requirement when the synthetic gas enters into the gas turbine.

- In the light of the high sulfur content in the coking coal, desulfuration method with low energy consumption, small investment and operation fee, high efficiency should be used. Dasulfurated resurgent gases rich in $\mathrm{H}_{2} \mathrm{~S}$ should go through sulfur recovery treatment, and the recovery product should be elemental sulfur or sulphuric acid. The purified synthetic gas goes into the combined cycle island after saturated heat exchange and heat up. Torch assembly should be in the factory.

- Large scale air separation unit, and through absorbent refining compression method, the process integration rate is between $0 \%$ and $60 \%$. According to the demand of the market, it is desirable to extract $\mathrm{Ar}$ through the process of rectification and get purified Ar product. The product oxygen and nitrogen should be compressed to standard pressure rating following the requirements of gasification and power generation process.

- The equipment for combined cycle is uni-axial/multiaxial. Use gas turbine fueled by combustible \#0 light diesel oil and synthetic gas, multi-stressed natural or forced circulation boiler with a hrsg (heat recovery steam generator) without supplementary firing, and reheat double flow condensing steam turbine.

- The equipment and control system should be advanced and compatible with the control system of IGCC power plant, capable of overseeing, controlling and protecting various operating modes in the power plant.

- The electrical equipment should be reliable and runs safely, continuously and steadily. The variation range of the electric voltage should be $10 \%$ higher or lower than the rated voltage, with the frequency range between 48.5 - $50.5 \mathrm{HZ}$.

The four potential IGCC installment plans of Yantai IGCC project were discussed and the principal performance index is in Table 1. 
Table 1. Principal performance index for IGCC’s desulfuration technique.

\begin{tabular}{|c|c|c|c|c|}
\hline Plan & Texaco + GE & SHELL + GE & Texaco + Siemens & SHELL + Siemens \\
\hline $\begin{array}{l}\text { Calculated value of efficiency of } \\
\text { the factory } \% \text { (without BOP) }\end{array}$ & $42.21 \%$ & $43 \%$ & $38.47 \%$ & $39.02 \%$ \\
\hline $\begin{array}{l}\text { Net generating capacity (MW) } \\
\text { (without BOP) }\end{array}$ & 429.62 & 401.46 & 265.9 & 236.7 \\
\hline Gasifier & $\begin{array}{l}\text { feeding in coal water } \\
\text { mixture and heat } \\
\text { recovery jet-flow gasifier }\end{array}$ & $\begin{array}{l}\text { Feeding in dry powder } \\
\text { jet-flow gasifier }\end{array}$ & $\begin{array}{c}\text { feeding in coal water } \\
\text { mixture and heat recovery } \\
\text { jet-flow gasifier }\end{array}$ & $\begin{array}{l}\text { Feeding in dry } \\
\text { powder jet-flow } \\
\text { gasifier }\end{array}$ \\
\hline Amount of coal $(\mathrm{t} / \mathrm{d})$ as received & 3506 & 3217 & 2381 & 2091 \\
\hline $\begin{array}{l}\text { Efficiency of the cooled coal gas } \% \\
\text { (at the outlet of the gasifier) }\end{array}$ & $72.31 \%$ & $83.44 \%$ & $72.31 \%$ & $82.14 \%$ \\
\hline Carbon convert ratio $(\%)$ & $98.30 \%$ & $99.30 \%$ & $98.30 \%$ & $99.30 \%$ \\
\hline Operation temperature of the gasifier $\left({ }^{\circ} \mathrm{C}\right)$ & 1397 & 1500 & 1397 & 1450 \\
\hline \multicolumn{5}{|l|}{$\begin{array}{l}\text { Components of the synthetic gas } \\
\text { at the outlet of the gasifier }\end{array}$} \\
\hline $\mathrm{CO}$ & $35.88 \%$ & $62.10 \%$ & $35.88 \%$ & $62.40 \%$ \\
\hline $\mathrm{H}_{2}$ & $29.15 \%$ & $29.20 \%$ & $29.15 \%$ & $29.40 \%$ \\
\hline $\mathrm{CO}_{2}$ & $13.94 \%$ & $1.00 \%$ & $13.94 \%$ & $1.00 \%$ \\
\hline $\mathrm{H}_{2} \mathrm{O}$ & $18.04 \%$ & $7.70 \%$ & $18.04 \%$ & $7.30 \%$ \\
\hline $\mathrm{CH}_{4}$ & $0.08 \%$ & $0.015 \%$ & $0.08 \%$ & $0.01 \%$ \\
\hline $\mathrm{Ar}$ & $0.96 \%$ & $0.00 \%$ & $0.96 \%$ & $0.00 \%$ \\
\hline $\mathrm{N}_{2}$ & $0.76 \%$ & $0.00 \%$ & $0.76 \%$ & $0.00 \%$ \\
\hline $\mathrm{COS}$ & $0.06 \%$ & $0.00 \%$ & $0.06 \%$ & $0.00 \%$ \\
\hline Gas generating capacity (kg/h) & 311880 & 234720 & 211767 & 150120 \\
\hline Gross output of the power island (MW) & 497.76 & 457.14 & 313.30 & 282.0 \\
\hline $\begin{array}{c}\text { Energy consumption of } \\
\text { space division island (MW) }\end{array}$ & 55.8 & 48.7 & 34.60 & 34.0 \\
\hline $\begin{array}{l}\text { Energy consumption of } \\
\text { gasification island(MW) }\end{array}$ & 5.4 & 5.6 & 3.40 & 4.0 \\
\hline $\begin{array}{l}\text { Energy consumption of the } \\
\text { desulfuration island (MW) }\end{array}$ & 1.1 & 1.5 & 1.00 & 1.0 \\
\hline $\begin{array}{l}\text { Energy consumption of } \\
\text { the power island (MW) }\end{array}$ & 5.84 & 5.08 & 8.40 & 6.3 \\
\hline Machine set pattern of the power island & Uni-axle & Uni-axle & Multi-axles & Multi-axles \\
\hline Gas turbine model & PG9351FA & PG9351FA & V94.2K & V94.2K \\
\hline Gas turbine output (MW) & 286 & 286 & 163.3 & 166.7 \\
\hline \multicolumn{5}{|l|}{$\begin{array}{l}\text { Components of the synthetic gas } \\
\text { at the outlet of the gas turbine }\end{array}$} \\
\hline $\mathrm{CO}$ & $35.79 \%$ & $51.96 \%$ & $44.72 \%$ & $62.40 \%$ \\
\hline $\mathrm{H}_{2}$ & $29.08 \%$ & $24.42 \%$ & $36.34 \%$ & $29.40 \%$ \\
\hline $\mathrm{CO}_{2}$ & $12.59 \%$ & $0.84 \%$ & $15.75 \%$ & $1.00 \%$ \\
\hline $\mathrm{H}_{2} \mathrm{O}$ & $20.12 \%$ & $16.41 \%$ & $0.17 \%$ & $0.40 \%$ \\
\hline $\mathrm{CH}_{4}$ & $0.08 \%$ & $0.03 \%$ & $0.10 \%$ & $0.01 \%$ \\
\hline
\end{tabular}




\begin{tabular}{|c|c|c|c|c|}
\hline $\mathrm{Ar}$ & $0.96 \%$ & $0.67 \%$ & $1.20 \%$ & $0.80 \%$ \\
\hline $\mathrm{N}_{2}$ & $1.37 \%$ & $5.65 \%$ & $1.71 \%$ & $6.00 \%$ \\
\hline $\mathrm{H}_{2} \mathrm{~S}$ & $0.01 \%$ & $0.01 \%$ & $0.01 \%$ & $0.005 \%$ \\
\hline $\cos$ & $0.00 \%$ & $0.00 \%$ & $0.00 \%$ & $0.00 \%$ \\
\hline LHV (MJ/Nm3) & 7.69 & 9.22 & 9.61 & 11.06 \\
\hline Inlet pressure $(\mathrm{MPa})$ & 3.1 & 2.59 & 1.8 & 1.8 \\
\hline HRSG & $\begin{array}{l}\text { Natural circulation } \\
\text { horizontal dual pressed } \\
\text { reheat HRSG }\end{array}$ & $\begin{array}{l}\text { Natural circulation } \\
\text { horizontal dual pressed } \\
\text { reheat HRSG }\end{array}$ & $\begin{array}{l}\text { Forced circulation } \\
\text { vertical dual pressed } \\
\text { reheat HRSG }\end{array}$ & $\begin{array}{c}\text { Triple pressed reheat } \\
\text { HRSG }\end{array}$ \\
\hline Steam turbine & $\begin{array}{l}\text { GE D10 } \\
\text { Dual pressed reheat double } \\
\text { flow steam turbine }\end{array}$ & $\begin{array}{l}\text { GE D10 } \\
\text { Dual pressed reheat double } \\
\text { flow steam turbine }\end{array}$ & $\begin{array}{l}\text { Double casing dual } \\
\text { pressed reheat double } \\
\text { flow steam turbine }\end{array}$ & $\begin{array}{l}\text { Double casing dual } \\
\text { pressed reheat double } \\
\text { flow steam turbine }\end{array}$ \\
\hline Steam turbine output (MW) & 211.76 & 171.1 & 149.966 & 115.3 \\
\hline Generator & $\begin{array}{l}\text { Bipolar synchronous } \\
\text { generators } \\
\text { Water-hydrogen cooling }\end{array}$ & $\begin{array}{l}\text { Bipolar synchronous } \\
\text { generators } \\
\text { Water-hydrogen cooling }\end{array}$ & $\begin{array}{l}\text { Bipolar synchronous } \\
\text { generators } \\
\text { Air cooling }\end{array}$ & $\begin{array}{l}\text { Bipolar synchronous } \\
\text { generators } \\
\text { Air cooling }\end{array}$ \\
\hline Desulfurization process & MDEA + Claus & Sulfinol + Claus + Scot & MDEA + Claus & Sulfinol + Claus + Soct \\
\hline Factory desulfurization efficiency (\%) & $>98$ & $>99.0$ & $>98$ & $>99.8$ \\
\hline Air integrative rate & 0 & $47 \%$ & $40 \%$ & $51 \%$ \\
\hline Oxygen compression rate & Oxygen compressor & $\begin{array}{l}\text { High-pressure liquid } \\
\text { oxygen pump }\end{array}$ & Oxygen compressor & $\begin{array}{l}\text { High-pressure liquid } \\
\text { oxygen pump }\end{array}$ \\
\hline
\end{tabular}

\section{Yantai IGCC Economic Attributes}

\subsection{Investment and Operation Cost}

Yantai IGCC project will construct a set of $300 \mathrm{MW}$ or $400 \mathrm{MW}$ level unit with the domestic coal as the fuel. The charges will be calculated and taken according to the 16th document Budget Management System and Regulations of Power Industrial Primary Construction and its relevant documents, which were issued in 2002 by China State Economic and Trade Commission.

This paper analyzed the investment of $400 \mathrm{MW}$ unit. According to the traits of IGCC generating unit, the investment of Yantai IGCC project can be divided into four parts, and the investment in foreign equipment and technologies of these four parts is as the following:

- Air separation part-including air separation and oxygen preparation, costs 23.29 million dollars.

- Gasification and purification part-gasificates and purifies coal (including bottom ash handling system, electric and thermal controlling system in this part), main equipment of the gasification island and patent technologies cost 71.8074 million dollars, while purification equipment costs 0.86 million dollars.

- Generator part-steam and gas turbine combinedcycle generator units (including electric controlling system of this part and the plant thermal controlling system) costs 125.3062 million dollars.

- Public part-fuel supply system, water treatment sys- tem, water supply system, auxiliary production project, and individual projects relevant to plant location.

The average feed-in tariff including tax of $300 \mathrm{MW}$ level and 400MW level IGCC power plant is 70.34 dollars/MWh and 58.11 dollars/MWh respectively, and the average feed-in tariff excluding tax is 60.23 dollars/ $\mathrm{MWh}$ and 49.76 dollars/MWh respectively, if estimate the operation economic effect with the standard coal price (including tax) 49.7 dollars/t and nation investment 60 million dollars. Presently, the feed-in tariff of common coal power plant is between 30.88 dollars/MWh and 51.47 dollars/MWh. IGCC construction cost varies with gasification and purification technologies, system combination, financing mode, and equipment material price. However, with China's principle "using market exchange technologies", the cost of IGCC plant construction will decrease dramatically if the gas turbine manufacturing technology is introduced and the three systems, gasification and purification, air separation and power island, are localized [6]. The main economic index of Yantai IGCC project can be seen in Table 2 .

\subsection{Sensitivity Analysis}

Among the factors influencing IGCC feed-in tariff, coal price and equipment production capacity utilization are the two most important factors [7]. Considering the analysis on localisation of equipment, we use investment as the third factors. Therefore, based on 300 MW IGCC 
Table 2. Principal performance index for IGCC’s desulfuration technique.

\begin{tabular}{cccc}
\hline & Unit & 400 MW level & 300 MW level \\
\hline Annual generating energy $(5426 \mathrm{~h})$ & $10^{8} \mathrm{kWh}$ & 21.32 & 13.01 \\
IGCC net efficiency (LHV) (dry) & $\%$ & 43 & 39 \\
Generation engineering static investment & 0.01 million dollars & 44,394 & 36,723 \\
Unit construction cost (gross output) & Dollar/kw & 949 & 1287 \\
Generation engineering dynamic investment & 0.01 million dollars & 477,513 & 39,419 \\
Unit construction cost (gross output) & Dollar/kw & 1189 & 1397 \\
Initial working capital & 0.01 million dollars & 135 & 68 \\
Project total capital & 0.01 million dollars & 47,886 & 39,487 \\
Annual production cost & 0.01 million dollars & 6272 & 4529 \\
Generating unit cost & Dollar $/ \mathrm{kw}$ & 29 & 34 \\
Average feed-in tariff (including tax) & Dollar $/ \mathrm{kw}$ & 58.11 & 70.34 \\
Average feed-in tariff (excluding tax) & Dollar/kw & 49.76 & 60.23 \\
\hline
\end{tabular}

project, this paper analyzes the sensitivity of feed-in tariff towards these three factors.

The measuring range of these three factors is:

- Coal price (including tax) measures sensitivity with $-10 \%$ and $+10 \%$;

- Equipment annual utilization hours measure sensitivity with 7000 hours, 6000 hours and 5000 hours

- Investment measures sensitivity with $-5 \%,+5 \%$, $+10 \%,+20 \%$ respectively.

The results are in Table 3.

The following conclusion can be got through the sensitivity analysis:

- Fuel charge is the largest proportion of the production cost, but the change of coal price is not the most sensitive factors influencing the feed-in tariff. If the coal price decreases by $10 \%$, the feed-in tariff will decrease 1.25 dollars/MWh. The decline rate is only $2.5 \%$. In domestic traditional power plant, the coal price's influence to feed-in tariff is rather sensitive, which means the IGCC can show its advantage when the price continuously increase.

- If the equipment utilization hours reduces 1000 hours, the feed-in tariff will increase 5.74 to 7.94 dollars/ MWh. In other words, the less the utilization hours is, the greater the impact it has on the feed-in tariff. Hence, the utilization hour should be reduced as much as possible. In fact, equipment utilization hour is restricted by power grid corporations and generating companies have no negotiating right, so the increase of utilization hours is need the electricity market reform as the premise.

- Investment change impact on the feed-in tariff is the most significant. The price will increase 3.54 dollars/ $\mathrm{MWh}$, when the investment increases by $10 \%$.
Table 3. Results of Yantai 300 MW project sensitivity analysis.

\begin{tabular}{|c|c|c|c|c|c|}
\hline \multirow{6}{*}{$\begin{array}{c}\text { Feed-in tariff } \\
\text { (excluding tax ) } \\
\text { Unit: } \\
\text { dollars/MWh }\end{array}$} & \multirow{2}{*}{ Investment } & $-5 \%$ & $+5 \%$ & $+10 \%$ & $+20 \%$ \\
\hline & & 58.34 & 62 & 63.77 & 67.24 \\
\hline & \multirow{2}{*}{$\begin{array}{c}\text { Equipment } \\
\text { utilization }\end{array}$} & 7000 hours & \multicolumn{2}{|c|}{6000 hours } & 5000 hours \\
\hline & & 50.32 & \multicolumn{2}{|c|}{56} & 63.99 \\
\hline & \multirow{2}{*}{ Coal price } & \multicolumn{2}{|c|}{$+10 \%$} & \multicolumn{2}{|r|}{$-10 \%$} \\
\hline & & \multicolumn{2}{|c|}{61.49} & \multicolumn{2}{|r|}{58.98} \\
\hline
\end{tabular}

\section{Reasons for the Delay of Yantai IGCC Project}

Yantai IGCC project is the first demonstration project in China, which has completed its bid invitation and evaluation for main equipments in 2002. In the recommendation, it has referred the gasifier and gas turbine equipment manufacturers, which were later reported to the State Planning Commission and Ministry of Electric Power. This project has originally planned to be started in June, 2004, and put into production in June, 2007. However, up to now, this project has not started. The IGCC project in Tianjin invested by Huaneng Group is the first demonstration project in Chinese mainland.

Three main reasons have caused the delay of Yantai IGCC project. First, China has a dispute on the necessity of IGCC project construction. Second, the key technologies and equipments rely too much on the foreign enterprise, which causes high investment and cost. Third, the ownership of this project is a bit controversial, which causes the responsibility unclear.

On the first problem, Chinese government has not formulated and promoted core leadership institution of en- 
ergy strategy for a long time, which causes the current system lack of an effective interest driving mechanism. Once involving cross-sectorial task of overall energy development, it is extremely difficult to coordinate and cooperate. Actually, China has carried out IGCC technology research. However, with the change of oil and electricity market, the attention on IGCC has gradually been cooled down. Meanwhile, during the project approval process, different departments paid different attention to IGCC, which caused the process exceptionally arduous and slow and the missing of the favorable investment opportunity. Until now, when IGCC is again listed in the national key development of coal power technology, the first IGCC project is started to construct.

In addition, China is lack of core products in key technologies and equipment, so it mainly relies on foreign technology providers and equipment suppliers. In the negotiation, China was in a passive position. Hence, the foreign quoted price was very high. The static investment was 0.44 billion dollars, among which the foreign equipment and technology investment in air separation, gasification, generator and public part has reached more than $50 \%$. The result was that it has further exacerbated the domestic controversy towards IGCC investment. The controversy centered on whether it was necessary for China to invest so much money for IGCC. In the dispute, the technical programs of Yantai IGCC project were also constantly adjusted, from initial $300 \mathrm{MW}$ to $100 \mathrm{MW}$, and the mian equipment has changed from import to partly domestic production. However, at that time, the IGCC equipment produced by China was just in pilot phase, so it was hard to use directly in the project.

Yantai IGCC project was initially constructed by The State Power Corporation, Shandong Electric Power Group Corporation, Yantai Electic Power Development Co., Ltd, and Shandong International Trust and Investment Corporation. At the end of 2002, the state power system reformed. The State Power Corporation was cancelled. The State Power Grid Corporation, The Southern Power Grid Corporation, five power generation companies and four auxiliary Companies, 11 companies in total, were founded, and power plants were supervised by power generation companies. Considering the absence of the power generation technology progress leader after the power system reform, The State Planning Commission decided that The State Grid Corporation was responsible for the organization and implementation since it owned the clean coal demonstration project, which can accelerate technology innovation and science progress and promote the sustained, rapid and sound development of electric power industry. But The State Grid Corporation was not responsible for power generation business, so it is not attractive for it to bear great risks to construct IGCC demonstration project. Then, the main project preparation company was Yantai Power Plant which belongs to Luneng Group, thus, the coordination is rather difficult. Moreover, the state view of IGCC project approval was not very positive, so after 2005 , this project was delayed. In early 2009, Yantai Power Plant belonged to Huaneng Group. It is also said that the project shares will be handed over to Huaneng Group by The State Power Corporation later.

\section{Conclusions}

Compared with the conventional PC + Flue gas desulfurization (FGD) and the second generation pressurized fluidized bed combustion (PFBC), IGCC has more advantages in purification effect and processing costs. From the economic analysis of Yantai project, Chinese ICGG project technical requirements at that time are basically the same as the current requirements. Further more, the demonstration scheme can completely meet the technical target. Only the core technologies and equipment were imported, so its overall cost was much higher than the conventional coal-fired thermal power units. From this point of view, the biggest obstacles for the IGCC promotion are investment and cost pressures. But with the social increasing demands on environmental protection, the continuous improvement and optimization of IGCC system, technology localization, and equipment of large scale production, the price difference between IGCC and conventional PC power plant will be gradually reduced.

Investments and the unit annual utilization hours have a rather obvious influence on the tariff, thus China should adopt policies which can encourage the introduction of advanced IGCC technologies and technical equipment localization to improve the unit utilization hours. Meanwhile, China should give preferential policies to the feed-in tariff of IGCC power generation to actively promote the popularization and application of IGCC technology. Moreover, if the country forfeits the PC power plant for its superfluous pollution, it will compensate for the disadvantage of IGCC high costs. With the construction of a series of demonstration power plant in China, it has accelerated IGCC technique verification, which is very important for the improvement of design and manufacturing level of IGCC plant corollary equipment, the reduce of the generating cost and the increase of the economic benefits.

All of these policies need a continuous and firm energy strategy as the support, and the strategy should be implemented by a unified coordination body. Even when the energy system changed dramatically, and abundant new technologies emerged, this coordination body can also implement the IGCC technology strategy according to the set objective. Only this method can make the research departments, investors and operators see clear 
commercial opportunities and market prospects, and promote IGCC through continuous investments.

\section{Acknowledgements}

This subject is aided financially by the National Natural Science Foundation of China (70941031, 71273075), Humanities and Social Science Foundation of Ministry of Education (09YJC790061), Heilongjiang Natural Science Foundation (QC08C72) and the Plan for Supporting the New Century Talents.

\section{REFERENCES}

[1] H. W. Liu, W. D. Ni, Z. Li and L. W. Ma, "Strategic Thinking on IGCC Development in China," Energy Policy, Vol. 36, No. 1, 2008, pp. 1-11. doi:10.1016/j.enpol.2007.08.034

[2] L. F. Zhao, Y. H. Xiao, K. S. Gallagher, B. Wang and X. $\mathrm{Xu}$, "Technical, Environmental, and Economic Assessment of Deploying Advanced Coal Power Technologies in the Chinese Context," Energy Policy, Vol. 36, No. 7, 2008, pp. 2709-2718. doi:10.1016/j.enpol.2008.03.028

[3] C. Chen and E. Rubin, " $\mathrm{CO}_{2}$ Control Technology Effects on IGCC Plant Performance and Cost," Energy Policy, Vol. 37, No. 3, 2009, pp. 915-924. doi:10.1016/j.enpol.2008.09.093

[4] D. X. Zhao, "Chinese IGCC Generation Technology Current Application and Policy Suggestion," Electric Power Technologic Economics, Vol. 19, No. 1, 2007, pp. 40-43.

[5] S. S. Xu and S. R. Wei, "IGCC and Novel Type Industrialization of Coal Power," Shanghai Electric Power, Vol. 5, No. 2, 2005, pp. 446-451.

[6] W. Y. Wang and Z. Fang, "Chinese Thermal Power Structure Optimization and Upgrade Technology Research," Collection of the 40th anniversary of the Chinese Society of power Engineering, 2002, pp. 161-181.

[7] G. R. Arcia, P. Douglas, E. Croiset and L. G. Zheng, "Techno Economic Evaluation of IGCC Power Plants for $\mathrm{CO}_{2}$ Avoidance," Energy Conversion and Management, Vol. 47, No. 15-16, 2006, pp. 2250-2259. doi:10.1016/j.enconman.2005.11.020 